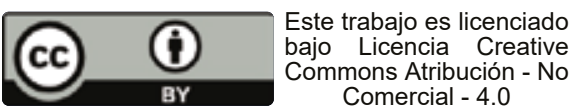

\title{
INFECCION POR CLAMIDIA
}

\section{CHLAMYDIA INFECTION}

\author{
doi: https://doi.org/10.35563/rmp.v8i1.8
}

Jorge Ybaseta - Medina ${ }^{1,2, a}$.

1. Profesor de la Universidad Nacional San Luis Gonzaga de Ica, Perú.

2. Hospital Santa María del Socorro. Ica, Perú.

a. Médico especialista en ginecología y obstetricia.

La Clamidia trachomatis es un organismo intracelular obligado que preferentemente infecta a las células de la zona de transición del cérvix (1). La infección por clamidias es considerada una infección de transmisión sexual (ITS) frecuente que puede infectar tanto a los dos sexos generalmente pacientes cuyo contacto sexual sea nuevo o múltiple, llegando a causar daños en el aparato reproductor femenino produciendo graves consecuencias sobre la salud reproductiva de las mujeres incluso esta bacteria puede ser adquirida por el recién nacido durante el parto $(1,2)$.

Las infecciones por Clamidia trachomatis son las más frecuentes y costosas de las ITS bacterianas, en los estudios reportados en la literatura mundial consignan prevalencias de esta enfermedad entre 1,7\% a $15 \%$ puediendo llegar a un $30 \%$ en algunas poblaciones, siendo más alta en el grupo etario menor de 25 años. Aproximadamente de un 20 a 40\% de las mujeres sexualmente activas tienen títulos positivos de anticuerpos por microinmunofluorescencia frente a Clamidia, los factores de riesgo para esta infección incluyen menors de 25 años, múltiples compañeros sexuales, inicio temprano.de relaciones sexuales, tabaquismo y consumo de drogas ilícitas (2).

Esta infección bacteriana coloniza el endocérvix y ascienden al endometrio, trompas y ovario produciendo endocervicitis, endometritis, ooforitis, parametritis, peritonitis pero principalmente salpingitis con o sin abscesos hasta en un $75 \%$ de los casos ocurren durante la fase folicular del ciclo menstrual donde existe un ambiente alto en estrógenos aunado a la presencia de la ectopia cervical encontrada en la adolescencia facilita la unión de la clamidia pudiendo causar a cervicitis y salpingitis (3).

Sin embargo, las infecciones por Clamidia suelen ser asíntomática en un $30 \%$ a $50 \%$ de los casos y puede persistir durante años, los pacientes con cervicitis por esta enfermedad pueden presentar flujo vaginal mucopurulento amarillo-verdoso, ardor al orinar, dolor en la parte baja del abdomen, fiebre, nauseas, relaciones sexuales dolorosas, sangrado post coital. Si estos pacientes no reciben tratamiento progresan con mas frecuencia a enfermedad inflamatoria pélvica motivo de embarazo ectópico e infertilidad (4).

Considerandose que la posible existencia de una coinfección con gonorrea entre las primeras opciones de tratamiento se incluye a la azitromicina y doxiciclina. Para prevención se recomienda la práctica de sexo con protección, siendo importante la indicación de examenes de laboratorio para detectar infección por clamidia trachomatis incluso en pacientes asíntomaticas (4). 


\section{REFERENCIA BIBLIOGRÁFICAS}

1. Cynthia Marrou Porras. Enfermedad pélvica inflamatoria y cultivo endocervical centro médico naval del perú cirujano mayor santiago távara 2017-2018. [Tesis para optar el Título de Segunda Especialidad en Ginecología y Obstetriciade]. Perú. Universidad San Martín de Porres. Facultad de Medicina; 2017.

http://www.repositorioacademico.usmp.edu.pe/ bitstream/usmp/3390/3/marrou_pcm.pdf

2. Castillo Gutiérrez, A. L. (2017). Asociación de infección por Chlamydia trachomatis con el diagnóstico de cervicitis aguda. MedUNAB, 19(3), 190-191.

https://revistas.unab.edu.co/index.php/medunab /article/view/2631R
3. Leidy Vásquez Valerio. Enfermedad inflamatoria pélvica. Revista Médica Sinergia. 2017; (2) 12:11-14

http://revistamedicasinergia.com/index.php/rms /article/view/102/165

4. Van de Laar M JW, Morré S A. Chlamydia: a major challenge for public health. Euro Surveill. 2007;12(10):pii=735.

https://www.eurosurveillance.org/content/10.28 07/esm.12.10.00735-en

Citar como: Ybaseta -Medina Jorge. Las Clamidias: un desafio para la salud pública [editorial]. Rev méd panacea.2019; 8(1): 1-2

\section{PANACEA \\ universidad nacional san luis conzaga. ica, pero}

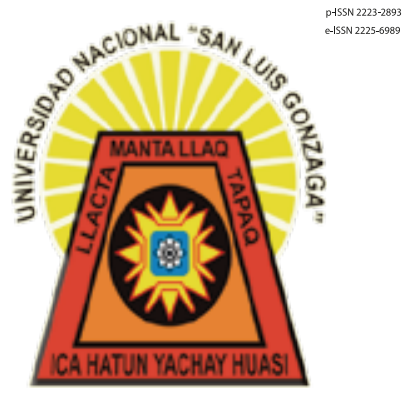

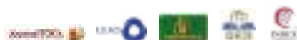

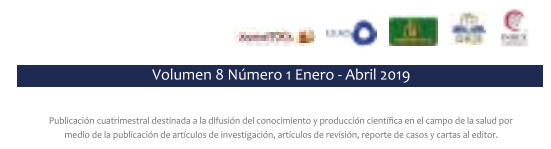

Jorge Ybaseta-Medina. Infeccion por clamidia. Rev méd panacea.2019; 8(1): 1-2 